\title{
Farmers' social economic and response determining application component technologies of "Jajar Legowo Super" technique: a case in Lampung
}

\author{
Enti Sirnawati ${ }^{1, *}$, Lira Mailena $^{1}$, and Dedi Suheimi $^{2}$ \\ ${ }^{1}$ Indonesia Center for Agricultural Technology Assesement and Development, Jln. Tentara Pelajar \\ No.10, Bogor \\ ${ }^{2}$ IPB University, Jln Raya Dramaga, Bogor
}

\begin{abstract}
Jajar Legowo Super' (Jarwo Super) technique is a technology package comprise of seven component technologies for maximum rice productivity. The technique is one of priority attention in IAARD's dissemination activity. This paper aims to identify how social, economic characteristics, farmers' response and application of the technology package. The unit analysis is the component technologies adopted in the Jarwo Super. The Data was taken from 43 farmers purposively (cooperator and non-co-operator) in Tanggamus, Lampung and did descriptive analysis. The results show that 'legowo' was the most known component in the jarwo super technique. In contrast inpari 30 was the most 'implemented and applied' components. Farmers dominantly use informal network to gather information through other farmers and community leaders. Further, their participation in training is relatively low due to the absence of these activities. However, access to mass media and radio is quite high, although usage internet access is still low. In term of economy aspect, 69 percent respondents use own finance and the rest use access banking and individuals including middlemen and kiosks. To conclude, farmers use single or partial component technology rather that adopt full package of the jarwo Super technique. Only reliable and available component will farmers' use.
\end{abstract}

\section{Introduction}

Indonesia Agricultural technology Assessment and Development (IAARD) is an instritution that develop and disseminate agricultural technology. These functions are to response and support challenges of food production and demand. The innovations are generated through Research and Development (R\&D) in food crops, horticulture, plantations, animal husbandry, land and environmental resources, mechanization, and post-harvest in creating new superior varieties, models or prototypes. The innovations are then introduced to stakeholders or users through dissemination activities. According to [1], dissemination is an

\footnotetext{
* Corresponding Author: entisw@hotmail.com
} 
activity of delivering results or technology of a research or studies to public or users. The activities are delivered using methods or media or technology packages tailored with technology type, agroecosystems, and socioeconomic characteristics of the community [23].

One of massive technology disseminated was 'Jajar Legowo Super' (Jarwo Super) technique; a technology package for maximum rain fed rice productivity. The technique is a development from legowo planting that complement with other technology to maximize rice production. Thus, the technique called Jarwo super; a technology package comprise of of: i) planting legowo 2:1 (see [4] for detail), ii) usage superior varieties with high yield potential, iii) usage biodecomposer for soil treatment, iv) usage agrimeth as biological, v) usage bioprotector and inorganic pesticides, and vii) usage transplanter for seedling and vi) usage harvester when harvesting [5]. The Jarwo Super technique has potential to produce higher unhusked rice cultivation [5].

Furthermore, the effective dissemination of Jarwo Super technique is determined by number of adoption. Measurement the adoption is a reflection from its feedback [6] on how the technique contributes in increased productivity. Definition of adoption that still relevant and widely used refers to the concept of [7] which states that adoption is one mental process progresses gradually; start from hearing or knowing innovation (knowledge), determining attitudes towards innovation (persuasion/interest), deaccessioning accept or reject the innovation (decision), adapt and apply the innovation (implementation/trial), and confirm to continuous use (confirmation/apply). This flow can fall into different levels of adopters, namely innovators, early adopters, early majority, late majority, and laggards. Eventually, each stage in those process is influenced by (1) innovators, including characteristics of recipients and the urge need for innovation, (2) social system including norms, tolerance, and integrated communication, (3) characteristics or nature of innovation including relative advantages, compatibility, complexity, ease of trying, and ease of being observed, and (4) communication channels. The adoption or application technology is also influenced by dissemination process, learning activities including frequency of training and extension facilitation [8], social and economic factors [9], and incentives [10]. Farmers' characteristics such as age and education levels, distance to information sources including extension services, and yield productivity greatly affect adoption level [11].

Jarwo super technique is predicted to support rice productivity. However there has been no study to evaluate or to assess how contribution of each component into the success application of the technique. Therefore, this paper aims to identify adoption of technology component in the jarwo super package; how socioeconomic characteristics and farmers' perceptions of technological advantage affect successful application of jarwo super technique.

\section{Method of Data Collection}

\subsection{Data Collection}

Study was conducted in Banjarmanis Village, Gisting District, Tanggamus, Lampung Province. Site selection was based on representation of agroecosystems, provinces, and commodities. The numbers of samples in this study were 42 farmers consisting of 19 cooperator and 23 non-cooperator farmers. Respondents were selected randomly from cooperator and non-cooperator farmers. The sample size was determined based on the minimum standard number of at least 30 samples. Samples less than 30 will give inconsistent results so that the quality of the sample is more important than just size [12]. 
Data were collected through interviews by using questionnaire and did observation. Two main cluster of the data collection were: First, adoption level of each component technology used in Jarwo Super. Second, comprise of respondent characteristics, social and economic characteristic, and responses to the component technology advantages. The level was identification by the asking farmers had or has been using those component technologies then identified the result into know, try and apply. These adoption categories refer to the study of $[13,14]$. The score 1 means they did and score 0 if did not. Below is information to determine the adoption level [13].

Knowledge : farmer ever heard, know, and understand the component technologies Implementing : farmers used the technology during the program/the introduction phase Application : farmers have been using the technology when the study did.

Furthermore, variables and indicators gathered for the second cluster as the following table:

\begin{tabular}{|l|l|}
\hline Variables & Indicators \\
\hline Respondents characteristics & $\begin{array}{l}\text { Age, education formal and informal (frec) year of farming, number of } \\
\text { family member, main and side job }\end{array}$ \\
\hline Social characteristics & $\begin{array}{l}\text { Frequency mobility outside village, frequency contact with extension, } \\
\text { frequency communication with farmers outside village, with } \\
\text { community leaders, and with government officer }\end{array}$ \\
\hline & $\begin{array}{l}\text { Frequency attending group meeting, counselling, participating in } \\
\text { training, assistance, frequency accessing media communication }\end{array}$ \\
\hline & $\begin{array}{l}\text { Innovativeness: innovator, early adopter, early majority, late majority, } \\
\text { laggard }\end{array}$ \\
\hline Economic characteristics & Source of capital: bank cooperative, individual \\
\hline Technologies advantages & Profitability, suitability, complexity, trial ability, observability \\
\hline
\end{tabular}

\subsection{Data Analysis}

Data obtained for the adoption rate was analysed descriptive how many farmers rating the adoption for each category (knowledge, implement, application) by presenting its cumulative data. Meanwhile, variables and indicators in the second cluster were analysed using descriptive statistical analysis. The analysis is performed by giving a score on each data then tabulated, classified and calculated the answers according to frequency and percentage based on answer categories. The entire data was processed using frequency distribution tabulation. Data processing was performed using SPSS version 24 and Microsoft excel programs. Data was presented separately between co-operator and non-cooperator.

\section{Results and Discussion}

\subsection{Description of research location}

Gisting District located $12 \mathrm{~km}$ from Tanggamus and $75 \mathrm{~km}$ from the Capital of Lampung Province (Bandar Lampung). Banjarmanis Village can be reached about 2 to 3 hours from Bandar Lampung. The village have good accessibility and road conditions with asphalted roads and fit with four-wheeled vehicles. Gisting district, with a total area of about 3,253 ha, has altitude of $500 \mathrm{~m}$ above sea level with temperature range from $20^{\circ} \mathrm{C}-35^{\circ} \mathrm{C}$. The average rainfall is quite high with 8 months of wet and 4 months of dry months. With those characteristics, Gisting is suitable for agricultural activities. 


\subsection{Characteristics of respondents}

The characteristics of respondents reflect the intrinsic performance of farmers. The characteristics observed included age, level of education, number of family members, type of main job, income and land owned. Studies of [15-16] revealed that those variables have a significant influenced of farmer adoption.

Respondents' age clearly illustrate that most of them are in productive age, with an average age of 47 years. Their level of education is also quite support the adoption process. The higher the level of farmers' education, the increased chance of adoption is [16-17]. Meanwhile, the cooperator farmers mostly finished junior high school, while those in noncooperator have completed primary school. In addition, farmers' involvement in training activities (informal education) is moderate; all co-operators had involved in other informal education or training activities. They attended training twice a year. However, this frequency is still low because farmers need training more often. Therefore, this condition reflects low access and activities on increasing farmers' knowledge and skills. As a result this situation has affected farmers' capacity to participate in a decision making. As a result, farmer's capacity influences the sustainability of technology adoption [18-19].

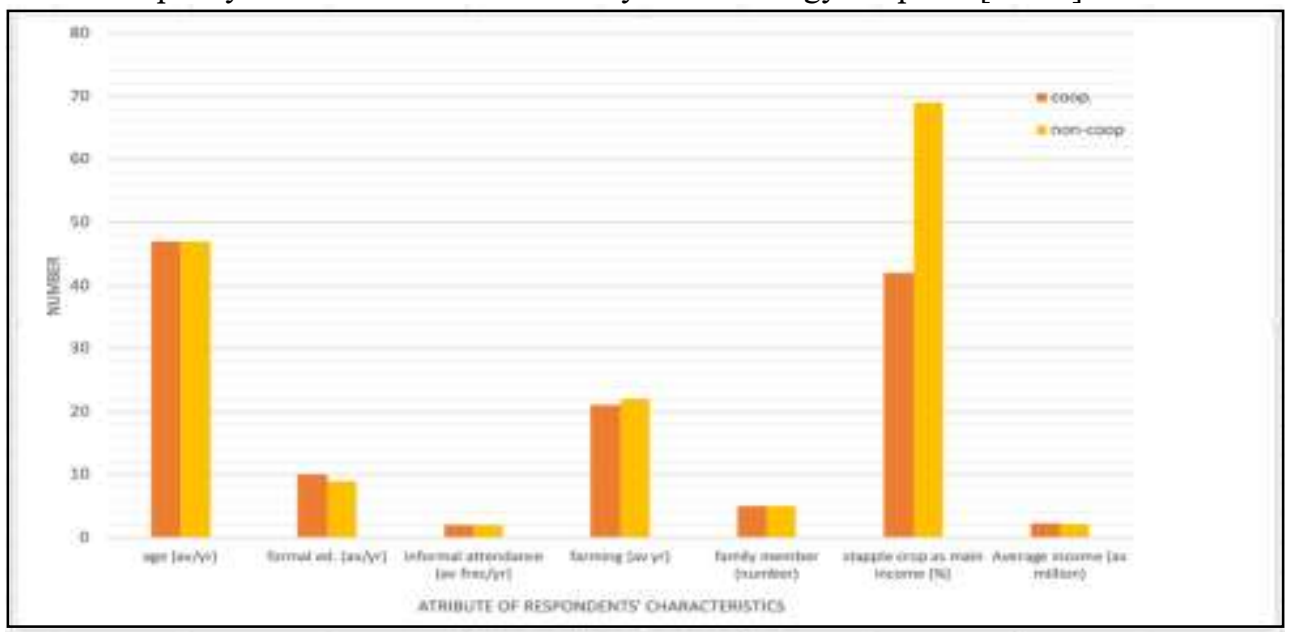

Fig. 1. Respondents' characteristics in Banjarmanis, 2018. Source: primary data (2018).

The number of family dependents is interesting to note; it illustrates farming's orientation and potential of family workforce for managing farming. Generally farmers with a large number of dependents will more focus in managing the rice farming to fulfil family needs. Instead, those with small family workforce will begin to develop profitable businesses. In this study, the average number of family dependents owned is five people. Results of the interview found their orientation was to get profit.

In addition, food crops are the main occupation and source of income for farmers in Gisting Village, as addition to the plantation business. The percentage of those finding is around $83.3 \%$ for the cooperator and $70 \%$ for the non-cooperator. The average respondent's income was Rp 2.27 million/year for the cooperator and Rp 2.19 million/year for the noncooperator; which is not so much different. That income derived from 3.6 to 4.6 hectares of land ownership. Interesting to note that the income is relatively small compared to the farming area. Thus technologies that provide increased production will have a major effect on improving farmers' income and welfare. 


\subsection{Adoption components of Jarwo Super Technique}

Theory of the adoption stage is based on [7] cognitive perspective. The adoption proses flow as follow: knowing information or innovation; responding the innovation, testing or implementing, and confirming to continue or stop to implement an innovation. The study shows (fig.2) that legowo 2:1 was the most well-known among other components among respondents. This data means that the information on legowo has familiar for farmers. However, implementation and confirmation of the legowo was below other components. For example, varieties (76 and 60 percent for cooperator and non-cooperator respectively) were the most implemented component. The cooperator explained that the Inpari 30 and Inpari 32 varieties were suitable with their agroecosystem. In contrast, non-cooperator were more interested in the Inpari 32 because of its texture. In addition the inpari 32 taste is quite familiar for farmers.

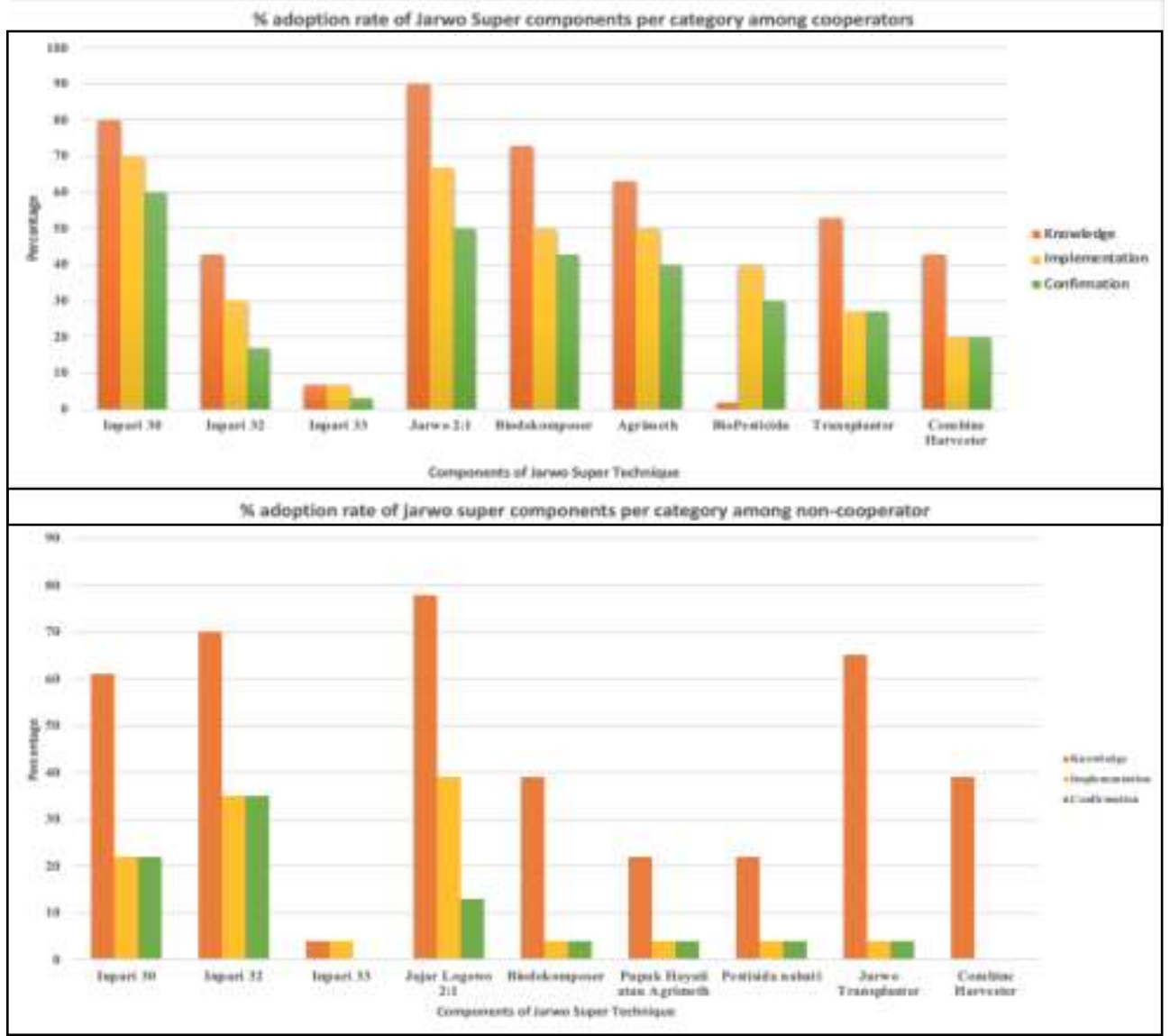

Fig. 2. Adoption of jarwo super component \%) in Banjarmanis, 2018 (primary data 2018).

Moreover, at the implementation stage of adoption, more than 70 percent of cooperators have used the Inpari 30 and the legowo. In addition, about 50 percent farmers have tried biodecomposer and agrimeth. In contrast, three other components (biopesticide, transplanter, harvester) had very low implementation; due to farmers' unconfident about its benefit.

Meanwhile non-cooperative respondents did try jarwo super technique voluntary without government support. The implementation stage for these farmers was below 40 percent, including the legowo (39.13\%), Inpari 32 (34.78\%) and Inpari 30 (21.74\%). Other 
components had not been tried because they contradict with existing farming culture. For example 'a bawon system' is a rice harvesting group that paid with 6:1 (6 for the group 1 for the farming owner). Introduction of transplanter and harvester will wipe plantation undermines the bawon system. Therefore, many planting groups reject the existence of transplants and combine harvesters the 'bawon system' off. Another reason for small adoption was about un-available of the machine by the time farmers need it, as also find in [20] study.

'Confirmation' in the adoption stage is an important point for whether or not an innovation is adopted [7]. The farmer evaluates the implementation that has been carried out and concludes whether or not to continue using components in jarwo super technique. According to the study, the components that farmers still apply were Inpari $30(60 \%)$, legowo $(50 \%)$, biodecomposer (40\%) and agrimeth (40\%). Meanwhile, those consecutive percentages for the non-cooperators were $21.7 ; 34.78$; and 13.04 percent respectively.

\subsection{Farmer's social, economic, and response on the jarwo super technique}

Description in this section will enrich findings on components adoption: why they had less percentage on the implementation and confirmation stage although they have good understanding and knowledge about the technology? We argue that frequency of interaction, source of farming funding, level of innovativeness, and perception of technology that have high contribution to the adoption level.

\subsubsection{Farmers' Social Characteristics}

Social characteristics can enrich information on factors influencing the adoption such as level of leadership, level of cosmopolitan, or level of social participation. Results shows that around $24 \%$ farmers actively join in farmer groups and even 70 percent of them were very active in mutual cooperation. Even so, respondent had a fairly good level of activity in the meeting which was illustrated by percentage of giving opinions in the group meeting. As many as $57.50 \%$ respondents gave opinions ranging from rarely to often, while the remaining $42.50 \%$ chose to be listeners or accept joint decisions. Of the $57.50 \%$ farmers who actively contributed to the meeting expressed their opinions become joint decision. As such, these opinions were considered represent members' opinions.

Table 1. The Level of Cosmopolitan of Respondent in the study site, 2018

\begin{tabular}{|c|l|c|}
\hline No & \multicolumn{1}{|c|}{ Indicators of Cosmopolitan } & \multicolumn{1}{|c|}{$\begin{array}{c}\text { Frequency in } \\
\text { one Month }\end{array}$} \\
\hline 1 & Take a trip outside the village related to farming business & 1 \\
\hline 2 & $\begin{array}{l}\text { Contact extension workers or other sources of information outside the } \\
\text { village related to farming }\end{array}$ & 2 \\
\hline 3 & Communicate with farmers outside the village & 3 \\
\hline 4 & Communicate with community leaders & 3 \\
\hline 5 & $\begin{array}{l}\text { Communicate with village / sub-district / district / provincial } \\
\text { governments }\end{array}$ & 1 \\
\hline
\end{tabular}

Social characteristics also are perceived from a cosmopolitanism level, communication intensity and participation with extension workers, as well as access to mass media. The cosmopolitan aspect illustrates the level of communication and interaction between farmers and people outside their social system and this aspect can reflect farmers' social networks with the outside world. From its frequency, farmers interacted at least 1 time per month, both with information sources, farmers outside the village and with community leaders. An interesting phenomenon was seen from the interaction of farmers with farmers outside the 
village and community leaders who are most often done three times a month. This result showed that farmers' efforts to make communication networks were more dominant informally through other farmers and community leaders (Table 1).

Moreover, the participation of farmers in farmer group meetings, counselling and assistance are presented in Table 2 . In one season, farmers generally participated in two farmer and extension groups meetings. This was considered lacking because farmers do not get the latest information as quickly as possible. Study by [21-22] revealed that farmers lacking of updated information has impacted on farming behaviour. Farmers 'participation in the training was only once in a season and the relative infrequency of farmers' participation in the training had no interest but due to the absence of these activities. This condition could be balanced by farmers by accessing mass media and radio that being the main choice of farmers in Tanggamus. Within a week, farmers access the radio twice with the main news about agriculture. However, access to website-based media such as the internet which had wider reach was relatively unused by farmers because interest was still low and knowledge levels were also limited.

Table 2. Average Participation of Respondent in meetings in the study site, 2018

\begin{tabular}{|c|l|c|}
\hline No & \multicolumn{1}{|c|}{ Social Characteristics } & Frequency \\
\hline 1 & Attends farmer group meetings in one season & 2 times \\
\hline 2 & Attending counselling conducted by extension agents in one season & 2 times \\
\hline 3 & Participate in training activities in one season & 1 time \\
\hline 4 & Participate in assisting activities in one season & 2 times \\
\hline 5 & The type of mass media that is often accessed related to agricultural activities & Radio \\
\hline 6 & Frequency of accessing Radio in a week & 2 times \\
\hline
\end{tabular}

\subsubsection{Innovativeness}

Analysis of farmers' innovativeness refers to five innovativeness category of an individual who becomes an adopter [7] namely laggard, late majority, early majority, early adopter and innovator. Respondent in Tanggamus, in general, were early majority and early adopter with a percentage of $47.62 \%$ (Fig.3). These results indicated that farmers were actually open farmers and receive new information and technology easily, but farmers still need time to directly implement such technology. As usual, farmers observed and wait for evidence of technology application from other farmers and needed to observe these results in one season. This condition was carried out by farmers in order to reduce the risk of implementing new technologies, given the farmers' limited capital capacity and the urgent living needs.

From the total respondents, only 2.38 percent belonged to the innovator group. They were farmers who are very open with new information and technology, decide fast, dare to take risks so that they can apply technology in a fast time. Conversely, the late majority group was that they were not quick to accept new information and technology and to implement it. Of the total respondents there were 2.38 percent of farmers belonging to the late majority group. An interesting phenomenon was that there were no respondent farmers classified as laggard, i.e. individuals who do not want to receive new information and technology and were not willing to apply. Associated with the distribution pattern of each innovative group, it has followed the distribution pattern of [7] as a normal distribution (bell-shaped) without the laggard group. 


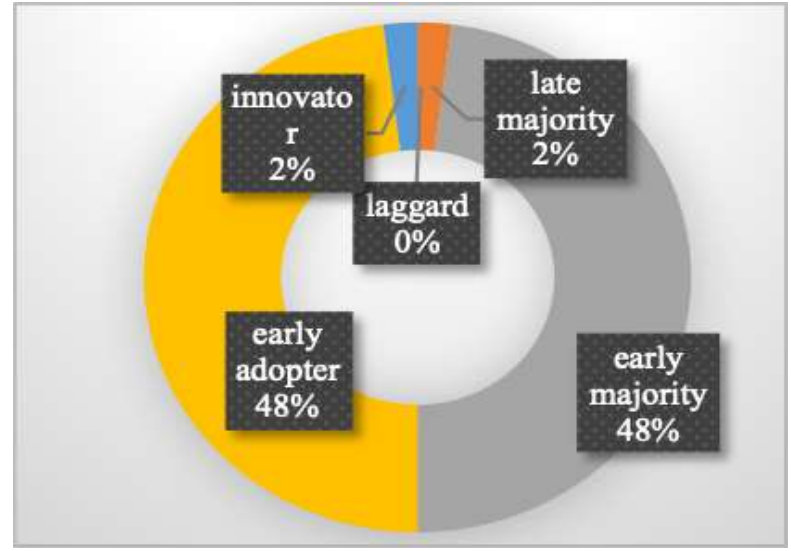

Fig 3. Farmers' Innovativeness

\subsubsection{Farmers' Economic Characteristic}

Farmer economic and business ability is believed to be determinant of adoption since the decision to adopt a technology is very dependent on the ability of farmers' capital. With adequate capital capability, farmers can make risky business decisions and vice versa. Meanwhile, farmers with limited capital tend to slow response to accept new innovations even though they clearly improve the farming business. Therefore, it is important to provide credit facilities under any prospective programs to support technology adoption for improved productivity [23-25].

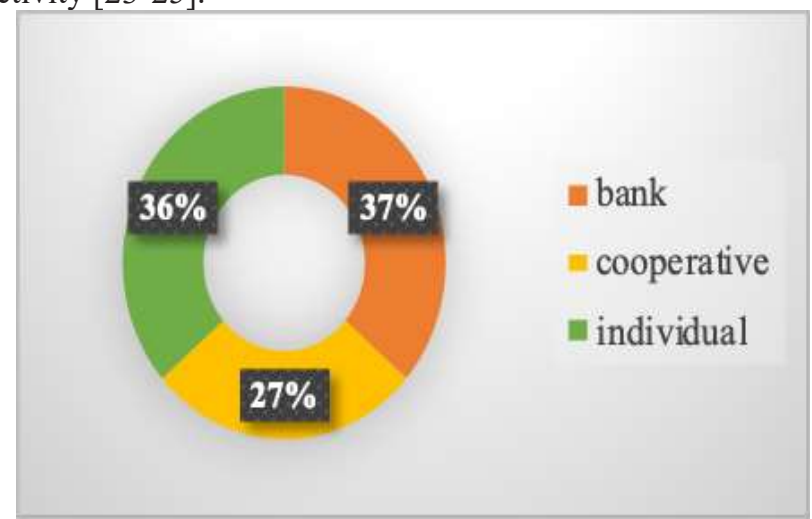

Fig. 4. Source of Farming fund

In addition, of 42 farmers who were being respondents, 69 percent financed their business from their own capital and the rest financed from their own capital and loans (Fig.4). There is no single farmer who financed the business from loans only. This condition was quite encouraging since farmers already had sufficient capital capability so that the process of technology adoption was expected to be faster and more sustainably. The main funding sources accessed by farmers were banking institutions and individuals, including middlemen and input store. The percentage of farmers who access these two sources of loans was 36.36 percent and 27.27 percent, respectively. Other sources of funding chosen by farmers were co-operators because it was considered safe and accommodate farmers' needs as well. 


\subsubsection{Perception on the components' Characteristic}

Characteristic of innovation is one of the determining variables in adoption. [7] Describes five characteristics of innovation that significantly affected on innovation adoption i.e. profitable, compatibility, and complexity, ease of testing and ease of access. The results of analysis related to farmers' perceptions on the characteristics attributes of the jarwo super technology discussed in the Fig.5. Regarding the characteristics in increasing the profit, bio decomposer, Inpari 32 and agrimeth were considered beneficial with the percentage of farmers on that response respectively 87.5 percent, 53.3 percent and 50.0 percent.

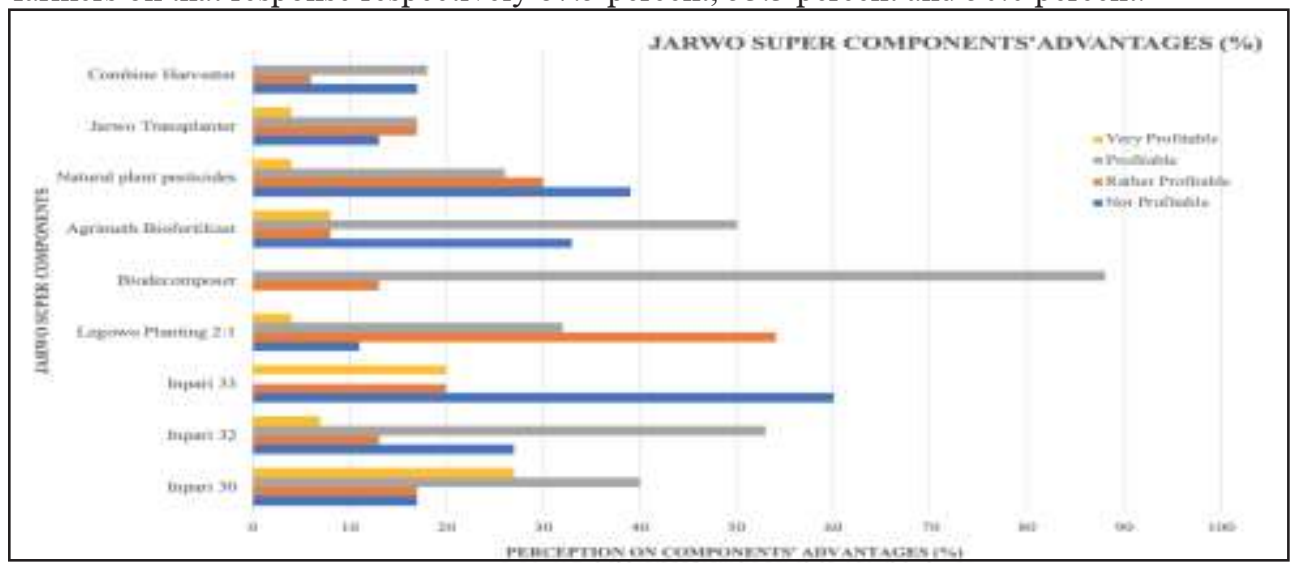

Fig. 5. Perceptions on the technology profitability at the study site, 2018 (primary data)

In terms of the suitability of technology there were three components that suitable to the land characteristics and agroecosystem in the research site namely Inpari 30, Inpari 32, biodecomposer biofertilizer and legowo. On the other hand, Inpari 33, biopesticide, transplanter and harvester were considered inappropriate on respondents' agroecosystem. This result the sama as in the adoption stage, where these components had poor low adoption stage.

Tabel 3. Perceptions on the Innovation Suitability at the study site, 2018

\begin{tabular}{|c|l|c|c|c|c|}
\hline \multirow{2}{*}{ No } & \multirow{2}{*}{ Component } & \multicolumn{4}{|c|}{ Suitability } \\
\cline { 3 - 6 } & & Not Suitable & Rather Suitable & Suitable & Very Suitable \\
\hline 1 & Inpari 30 & 3.7 & 11.1 & 81.5 & 3.7 \\
\hline 2 & Inpari 32 & 14.3 & 21.4 & 64.3 & 0.0 \\
\hline 3 & Inpari 33 & 50.0 & 50.0 & 0.0 & 0.0 \\
\hline 4 & Legowo Planting 2:1 & 7.1 & 35.7 & 53.6 & 3.6 \\
\hline 5 & Biodecomposer & 0.0 & 27.3 & 68.2 & 4.5 \\
\hline 6 & Agrimeth Biofertilizer & 33.3 & 12.5 & 54.2 & 0.0 \\
\hline 7 & Natural plant pesticides & 50.0 & 25.0 & 25.0 & 0.0 \\
\hline 8 & Jarwo Transplanter & 82.6 & 8.7 & 8.7 & 0.0 \\
\hline 9 & Combine Harvester & 81.0 & 4.8 & 14.3 & 0.0 \\
\hline
\end{tabular}

Source: primary data (analysed), 2018

Farmers' perceptions on complexity components of the Jarwo Super technique are presented in Table 4. Of the nine components, the transplanter and harvester were considered as complicated. This was revealed by 58.3 percent and 70 percent farmers respectively. In fact, 12.5 percent consider that the transplanter was very complicated. One reason for example the component was not yet widely understood, unsuitable with land condition, culture that use the bawon system. In contrast, Inpari 32, Inpari 30, 
biodecomposer and agrimeth were considered as easy to be implemented. The finding is inline with those in the adoption rate. The Inpari 33 still considered as a rather complicated technology because it easily collapses with long panicles that made difficult for farmers to maintain rice plantation during strong winds.

Table 4. Perceptions on the Technology Complexity at the study site, 2018

\begin{tabular}{|c|l|c|c|c|c|}
\hline \multirow{2}{*}{ No } & \multirow{2}{*}{ Component } & \multicolumn{4}{|c|}{ Complexity } \\
\cline { 3 - 6 } & & Very complex & complex & Rather complex & Not complex \\
\hline 1 & Inpari 30 & 6.9 & 3.4 & 34.5 & 55.2 \\
\hline 2 & Inpari 32 & 0.0 & 0.0 & 30.8 & 69.2 \\
\hline 3 & Inpari 33 & 0.0 & 0.0 & 66.7 & 33.3 \\
\hline 4 & Legowo Planting 2:1 & 10.7 & 17.1 & 46.4 & 35.7 \\
\hline 5 & Biodecomposer & 0.0 & 4.3 & 52.2 & 43.5 \\
\hline 6 & Agrimeth Biofertilizer & 0.0 & 8.7 & 43.5 & 47.8 \\
\hline 7 & Natural plant pesticides & 0.0 & 36.4 & 27.3 & 36.4 \\
\hline 8 & Jarwo Transplanter & 12.5 & 58.3 & 20.8 & 8.3 \\
\hline 9 & Combine Harvester & 10.0 & 70.0 & 20.0 & 00.0 \\
\hline
\end{tabular}

Source: primary data (analysed), 2018

The ease of being tested is the fourth characteristic that illustrates the ease of farmers in applying component without assistance and or applying the component on a wider scale. This criterion is very important because farmers are expected enable trying out the introduced technologies by themselves. New improved rice varieties again considered easy to be trial, as conveyed by 70.4 percent farmers for Inpari 30 and 61.5 percent for Inpari 32 . Likewise, with agrimeth where 62.5 percent farmers stated that biofertilizers were easily in application. Farmers could apply agrimeth in order to increase seed growth into young plants and increase rice seed resistance from fungi and other diseases as well. On the other hand, Inpari 33 was considered not easy to be used because the availability of seeds was very limited then farmers were less interested in using that variety.

Table 5. Perceptions on Technology Triability at the study site, 2018

\begin{tabular}{|c|l|c|c|c|c|}
\hline \multirow{2}{*}{ No } & \multicolumn{2}{|c|}{ Component } & \multicolumn{4}{|c|}{ Trialability } \\
\cline { 3 - 6 } & difficult & Less difficult & Easy & Very easy \\
\hline 1 & Inpari 30 & 7.4 & 3.7 & 70.4 & 18.5 \\
\hline 2 & Inpari 32 & 15.4 & 7.7 & 61.5 & 15.4 \\
\hline 3 & Inpari 33 & 50.0 & 25.0 & 0.0 & 25.0 \\
\hline 4 & Legowo Raw Planting 2:1 & 19.2 & 19.2 & 53.8 & 7.7 \\
\hline 5 & Biodecomposer & 0.0 & 43.5 & 39.1 & 17.4 \\
\hline 6 & Agrimeth Biofertilizer & 0.0 & 25.0 & 62.5 & 12.5 \\
\hline 7 & Natural plant pesticides & 18.2 & 27.3 & 50.0 & 4.5 \\
\hline 8 & Jarwo Transplanter & 26.1 & 34.8 & 34.8 & 4.3 \\
\hline 9 & Combine Harvester & 10.0 & 25.0 & 55.0 & 10.0 \\
\hline
\end{tabular}

Source: primary data (analysed), 2018

The last characteristic of technology influence adoption mentioned by [8] is the ease of the technology to be observed. This characteristic reflects result changes that farmers can be observed easily. Almost all components were easy to observe its changes, except for bio pesticides; since not all cooperator farmers used this. Because transplanter and harvester were indeed not often used by farmers, so the change in the application of these two technologies was also not easily be observed. 
Tabel 6. Perceptions on the Technology Observability at the study site, 2018

\begin{tabular}{|c|l|c|c|c|c|}
\hline No & \multirow{2}{*}{ Component } & \multicolumn{4}{|c|}{ Ease of Being Observed } \\
\cline { 3 - 6 } & & Not Easy & Rather Easy & Easy & Very Easy \\
\hline 1 & Inpari 30 & 0.0 & 9.1 & 72.7 & 18.2 \\
\hline 2 & Inpari 32 & 0.0 & 12.5 & 87.5 & 0.0 \\
\hline 3 & Inpari 33 & 0.0 & 33.3 & 66.7 & 0.0 \\
\hline 4 & Legowo Raw Planting 2:1 & 8.7 & 8.7 & 73.9 & 8.7 \\
\hline 5 & Biodecomposer & 0.0 & 0.0 & 89.5 & 10.5 \\
\hline 6 & Agrimeth Biofertilizer & 0.0 & 10.0 & 75.0 & 15.0 \\
\hline 7 & Natural plant pesticides & 0.0 & 52.6 & 26.3 & 21.1 \\
\hline 8 & Jarwo Transplanter & 15.8 & 5.3 & 68.4 & 10.5 \\
\hline 9 & Combine Harvester & 12.5 & 0.0 & 75.0 & 12.5 \\
\hline
\end{tabular}

Source: primary data (analysed), 2018

Meanwhile, 56.67 percent respondents said the jarwo super technique has proven increased productivity of 5-10 percent compared to existing technology. As well, 26.67 percent said the contribution of the technique's used on productivity was even greater; over 10-20 percent. Then, 16.67 percent confirm they productivity increased more than 20 percent. Moreover, increasing income has also become the expected impact from using the Jarwo Super. About 56.67 percent farmers said that the technology has pushed increased farmers' income 5 to $10 ; 30$ percent farmers gained increased over 10 to 20 percent ; and over 20 percent increased income for 13.33 respondents.

Summing up the components advantages, we present the above explanation as the following chart. The figure is presented into three categories: varieties, pesticide, and machinery. According to the figure, each component has high and low percentage of advantage. For example, Inpari 30 was the most accepted variety with moderate response; bio decomposer and agrimeth took a good perception; and fewer acceptances on the machineries although they are profitable.

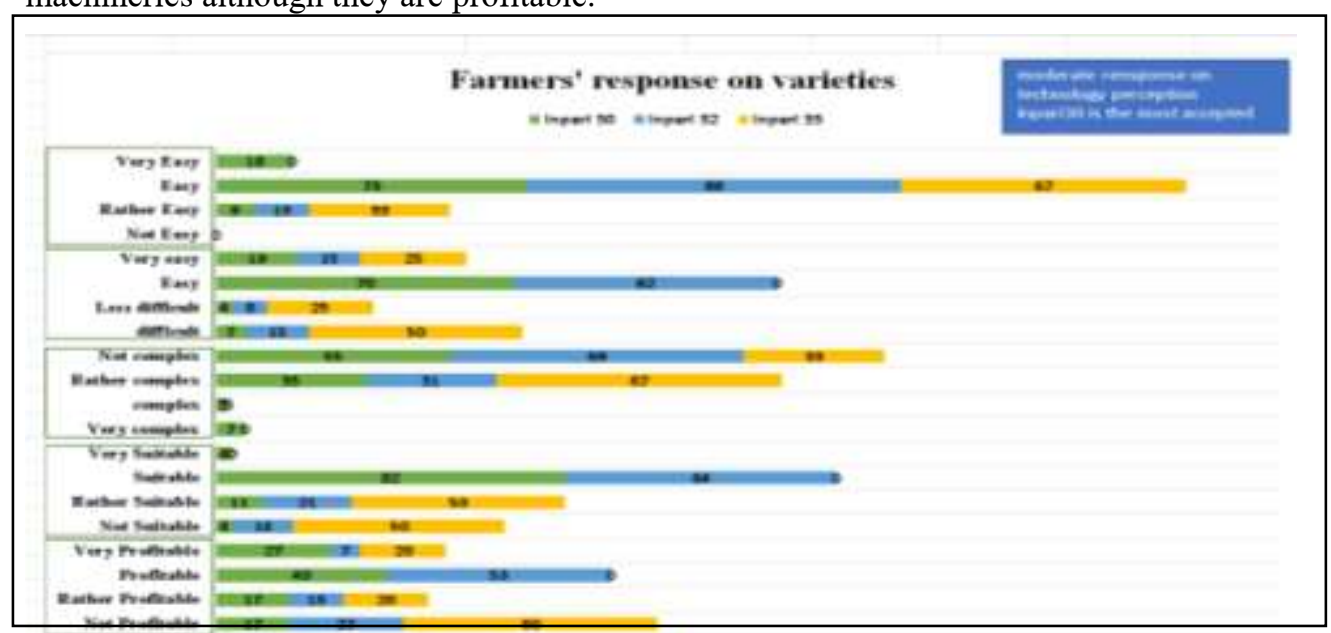




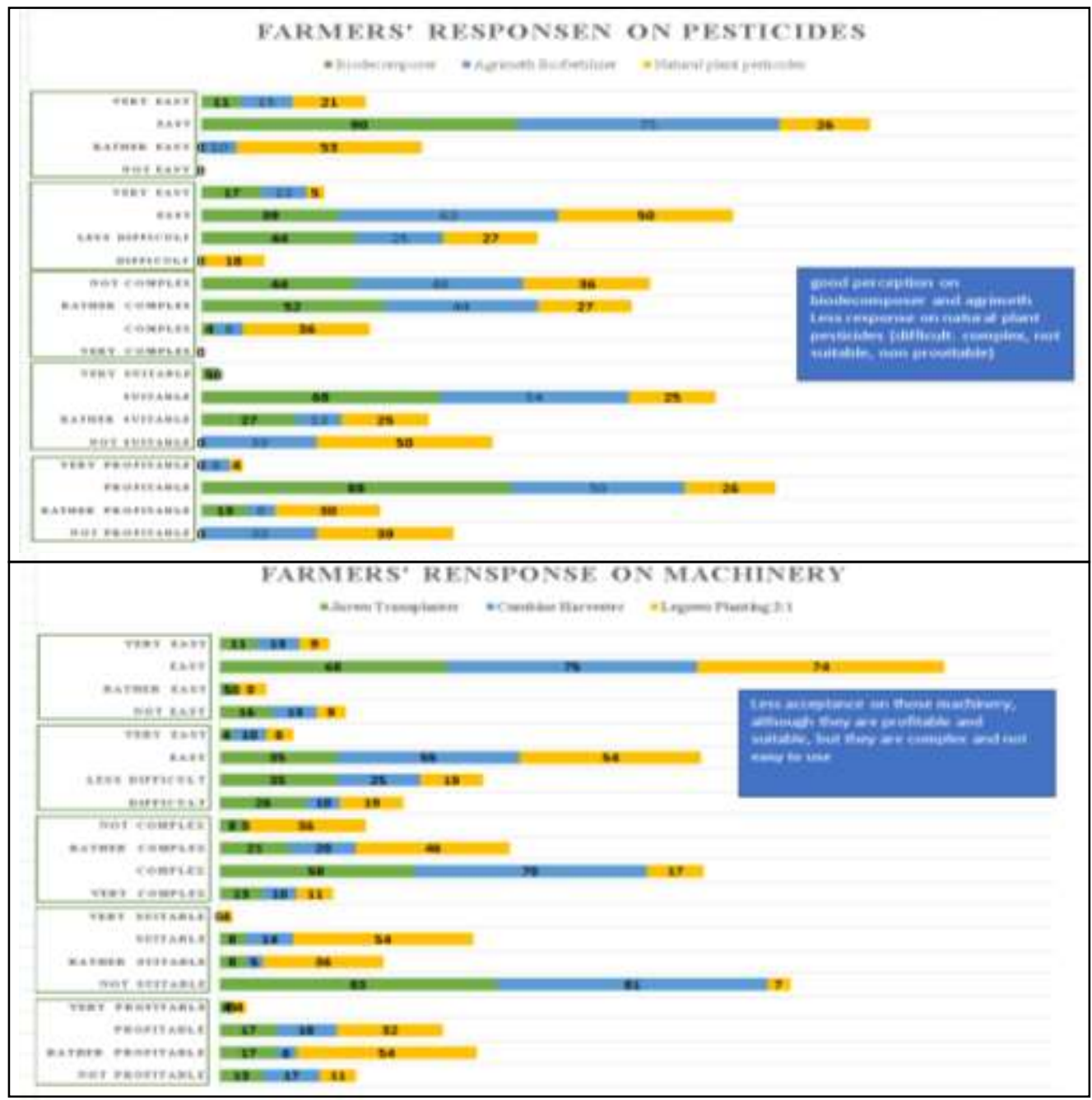

Fig. 6. Perception on the components advantage

\section{Conclusions}

Farmers use single or partial component rather adopt full package of the jarwo Super technique. Reliable and available components will farmer's used. Informal networking and capital capacity have a significance influence in disseminating the technique. The most components used in jarwo super technique were inpari 30 and legowo, As well, the legowo were the most welk nown component although its application/adoption was below inpari 32. Meanwhile, the application of transplanter and harvester were low.

Farmers' social participation was also low. Interestingly they are open minded on new innovation that reflects by quite number of early adopter. Communication networks were more dominant informally through other farmers and community leaders. Economic characteristic reflected by farmer's capital, showed that most of them financed their business from their own capital.

Regarding technology benefit, farmers rated biodecomposer, Inpari 32 and agrimeth were considered beneficial. Inpari 30, Inpari 32, biodecomposer, biofertilizer and legowo 
are suitable to be implemented in respondents' area. Transplanter and harvester were considered as complicated technology.

Acknowledgement. Thank you to SMARTD for the research funds. Furthermore, sincere thanks to Dr. Haris Syahbuddin, Dr. Sudi Mardanto, Dr. Sumedi, Dr. Nizwar Syafaat, Vyta W. Hanifah, M.Sc, Yovita Anggita Dewi, M.Sc, Ir. Kiswanto, MS, Fauziah, MSi and Tisna Subarna, SP for their guidance and assistance in carrying out this study.

\section{References}

1. R. Djaffar, J. Penel. Kom. dan Opini. Publ., Diseminasi Teknologi Informasi Pada Masyarakat Nelayan di Kabupaten Takalar dan Barru 20(1): 73 - 87 (2017)

2. BA Awotide, AA Karimov, A. Diagne, Agric Econ, Agricultural technology adoption, commercialization and smallholder rice farmers' welfare in rural Nigeria. 4(3) (2016).

3. F.J. Dessart, J.B. Hurle, R.v. Bavel, Eur. Rev. of Agric. Econ., Behavioral factors affecting the adoption of sustainable farming practices: a policy-oriented review 46(3): 417-471 (2019)

4. Badan Penelitian dan Pengembangan Pertanian, Jakarta, Petunjuk teknis budidaya padi jajar legowo super, (2016)

5. G.R. Ikhwani, E Pratiwi, A.K. Paturrohman, Makarim, Iptek Tan. Pang., Peningkatan produktivitas padi melalui penerapan jarak tanam jajar legowo 8(2): $72-79$ (2013)

6. G. Kuehne, R. Liewellyn, D.J. Panel, R. Wikinson, P. Dolling, J. Ouzman, M. Ewing, Agric. Syst., Predicting farmer uptake of new agricultural practices: atool for research, extension and policy 156: 115-125 (2017)

7. E.M. Rogers, Free Press New York, Diffusion of innovations. Fifth Edition (2003)

8. M.S Sharifzadeh, C.A. Damalas, G. Abdollahzadeh, H.A. Gorgi, Crop Prot., Predicting adoption of biological control among Iranian rice farmers: An application of the extended technology acceptance model (TAM2) 96:88-96 (2017)

9. G. N. Umeh, V. A. Chukwu, J of Bio., Agr., and Hcare, Determinant of adoption. of improved rice production technologies in Ebonyi State of Nigeria 5(7): 170-176 (2015)

10. L.A.A.T, Sambodo and P.L. Nuthall, The J. of Agric. Ed. and Ext., A behavioural approach to understanding semi-subsistence farmers' technology adoption decisions: the case of improved paddy-prawn system in Indonesia 6(2): 111-129 (2010)

11. A. Fatchiya, I. Muflikhati, T. Soedewo, J. Peny, Actors correlating with Adoption of the Integration System of Paddy-Livestock in Central Sulawesi Province, Indonesia 14(2) (2018).

12. M.A. Morisan, Kencana Jakarta, Metode Penelitian Survei, (2012)

13. BBP2TP, Badan Litbang Pertanian, Studi Adopsi Teknologi Hasil Balitbangtan: A Report (2018)

14. I. Lambrecht, B. Vanlauwe, R. Merckx, M. Maertens, World Dev. Understanding the Process of Agricultural Technology Adoption: Mineral Fertilizer in Eastern DR Congo 59: 132-146 (2014)

15. K.Takahashi and C.B. Barrett, Am. J. of Agric. Econ., The System of Rice Intensification and its Impacts on Household Income and Child Schooling: Evidence from Rural Indonesia 96(1): 269-289 (2013)

16. A.Ugochukwu and P.W.B. Phillips, From Agrisc. To Agribuss. Springer, Technology Adoption by Agricultural Producers: A Review of the Literature 361-377 (2018)

17. M. Mwangi, S. Kariuki, Factors Determining Adoption of New Agricultural Technology by Smallholder Farmers in Developing Countries, J.of Ec. and Sust. Dev. 6(5) (2015) 
18. S. Oreszczyn, A. Lane and S. Carr, J. of Rur. Stud., The role of networks of practice and webs of influencers on farmers' engagement with and learning about agricultural innovations 26: 404-417 (2010)

19. K.B.M. Noor, J. of Hum, and Soc. Sc., Investigating Training Impact on Farmers' Perception and Performance 1(6) (2011)

20. Vitriawati, A. Sapja, L. Evy, Russia J. of Ag. and Soc-Ec. Sc, The relationship of farmers socio economic conditions, the role of chairman of groups and authors with the innovation level of super legowo rice cultivation 1(85) (2019)

21. M.J.U. Din, Sarhad J. Agric., The socio economic problems of small farmers in adopting new agricultural technology a case study of three villages in district Mardan. 27(2): 299-304 (2011)

22. V. Darwis, C. Muslim, Y.H. Saputra, SOCA: Jurnal Sosial Ekonomi Pertanian, The Benefits and Problems in the Implementation of the Special Effort of Rice, Corn, Soybean Production Enhancement Program 14(3): 410-420 (2020)

23. B.S. Khattak, M. Kaleem, H.N. Waqas, M. Yasir, Sarhad J. of Agr., Socio-Economic development of small farmers by providing micro-credit facilities under the crop maximization project in district Charsadda, Pakistan 36(2): 389-396 (2020)

24. E. Yazhari, Dheli: Ben Grozier Operations Associate, Agriculture and food security at the BOP India and East Africa (2016)

25. FAO Representtaion in Pakistan, Pakistan and FAO Achievements and Success Stories (2011) 